\title{
Characterization of monoclonal antibodies against feline infectious peritonitis virus type II and antigenic relationship between feline, porcine, and canine coronaviruses
}

\author{
T. Hohdatsu' ${ }^{1}$ S. Okada ${ }^{2}$, and H. Koyama ${ }^{2}$ \\ Departments of ${ }^{1}$ Veterinary Microbiology and of ${ }^{2}$ Veterinary Infectious Diseases, School \\ of Veterinary Medicine and Animal Sciences, Kitasato University, Aomori-Ken, Japan \\ Accepted August 22, 1990
}

Summary. Seven monoclonal antibodies (MAbs) with neutralizing activity against feline infectious peritonitis virus (FIPV) strain 79-1149 (type II) were prepared. When the polypeptide specificity recognized by these monoclonal antibodies (MAbs) was investigated by Western immunoblotting, all of the $\mathrm{MAbs}$ reacted with peplomer glycoprotein (S) of the virus. By competitive binding assay these MAbs were found to recognize at least 3 different epitopes. The reactivity of these MAbs with 6 viruses classified as FIPV type I (UCD1, UCD-2, UCD-3, UCD-4, NW-1, and Black), feline enteric coronavirus (FECV) type II strain 79-1683, canine coronavirus (CCV) strain 1-71, and transmissible gastroenteritis virus (TGEV) strains TO-163 and SH was examined by neutralization tests. All MAbs neutralized FECV strain 79-1683, CCV strain 1-71, and TGEV strains TO-163 and SH, while they did not neutralize the 6 FIPV type I viruses. Moreover, the MAb against TGEV strain TO-163, which has strong neutralizing activity against $7 \mathrm{TGEV}$ viruses, neutralized CCV strain 1-71, FECV strain 79-1683, and FIPV strain 79-1146, but did not neutralize the 6 FIPV type I viruses.

These results demonstrated that there are at least 3 epitopes involved in the neutralization of FIPV type II strain 79-1146, and that these epitopes are not present in FIPV type I viruses but are present in FECV strain 79-1683 which does not induce feline infectious peritonitis, TGEV strains TO-163 and SH, and CCV strain 1-71. These results suggest the presence of 2 serotypes of FIPV which can be clearly distinguished by the neutralization test using MAbs.

\section{Introduction}

The mammalian members of the family Coronaviridae are divided into 2 distinct antigenic groups on the basis of serologic tests $[23,25]$. One antigenic group 
contains mouse hepatitis virus, neonatal calf diarrhea coronavirus, human coronavirus $\mathrm{HCV}-\mathrm{OC} 43$, hemagglutinating encephalomyelitis virus of swine, and rat coronavirus. The second antigenic group consists of human respiratory coronavirus HCV-229E, transmissible gastroenteritis virus (TGEV) of swine, canine coronavirus (CCV), and feline infectious peritonitis virus (FIPV) $[8,22]$. In addition to these members, a feline enteric coronavirus (FECV) has been isolated, which is very closely related to FIPV, TGEV, and CCV $[19,20]$.

Feline coronaviruses are divided into FIPV types I and II, and FECV types I and II, on the basis of the disease types, that is, whether it causes feline infectious peritonitis (FIP) or not, the ability of the viruses to proliferate in cell cultures, and the antigenic relationship to TGEV and CCV [17]. Among these types, FIPV type II and FECV type II are reported to be antigenically closer to TGEV and CCV. Between TGEV Purdue strain and FIPV 79-1146 strain a high degree of homology in the primary structure of the peplomer protein (S, 210k) has been described (39\% for amino acid residues 1 to 274 and $93 \%$ for residues 275 to 1447) [9]. The authors prepared MAbs which react only with the feline coronaviruses FIPV type II strain 79-1146 and FECV type II strain 79-1683. Some of these MAbs reacted with either TGEV or CCV in indirect fluorescent antibody assays. Also, some differences in antigenically between FIPV type I virus strains were noted in an analysis using MAbs (unpubl. obs.).

In this study, we prepared MAbs with neutralizing activity against FIPV strain 79-1146, and investigated the differences in the epitopes recognized by these MAbs, using a competitive binding assay. Using these MAbs and MAbs with neutralizing activity against TGEV strain TO-163, we examined the neutralizing epitopes for differences between feline coronaviruses, and TGEV and $\mathrm{CCV}$ viruses.

\section{Materials and methods}

\section{Cell cultures}

Feline whole fetus cells (fcwf-4), Crandell feline kidney cells (CrFK), and swine kidney cells (CPK) were grown in Eagle's minimum essential medium (MEM) containing $20 \% \mathrm{~L}$ 15 medium, $10 \%$ fetal calf serum, 100 units $/ \mathrm{ml}$ penicillin and $100 \mu \mathrm{g} / \mathrm{ml}$ streptomycin. The maintenance medium was MEM containing $20 \% \mathrm{~L}-15$ and antibiotics as above. The cells were maintained in a humidified $5 \% \mathrm{CO}_{2}$ incubator at $37^{\circ} \mathrm{C}$.

\section{Viruses}

The coronavirus isolates used in this study and their sources are shown in Table 1. Among the FIPV strains used in the study, strains UCD-1, NW-1, UCD-2, UCD-3, UCD-4, and Black show cell-associated growth, and are therefore regarded as type I virus strains in the classification of Pedersen et al. [17].

FIPV and FECV, TGEV, and CCV were passaged 2 or 3 times in fcwf- 4 cells, CPK cells, and CrFK cells, respectively, and were used for the study. 
Table 1. Source of coronavirus isolates

\begin{tabular}{|c|c|c|c|}
\hline \multicolumn{2}{|c|}{ Virus strain } & \multirow{2}{*}{$\begin{array}{l}\text { Source } \\
\text { M. C. Horzinek, } \\
\text { State University Utrecht }\end{array}$} & \multirow{2}{*}{$\frac{\text { Reference }}{[12,20]}$} \\
\hline FIPV & $79-1146$ & & \\
\hline & UCD-1 & $\begin{array}{l}\text { N. C. Pedersen, } \\
\text { University of California, Davis }\end{array}$ & {$[18,21]$} \\
\hline & NW-1 & $\begin{array}{l}\text { J. K. Yamamoto, } \\
\text { University of California, Davis }\end{array}$ & {$[14,18]$} \\
\hline & UCD-2 & $\begin{array}{l}\text { J. K. Yamamoto, } \\
\text { University of California, Davis }\end{array}$ & {$[16]$} \\
\hline & UCD-3 & $\begin{array}{l}\text { J. K. Yamamoto, } \\
\text { University of California, Davis }\end{array}$ & {$[16]$} \\
\hline & UCD-4 & $\begin{array}{l}\text { J. K. Yamamoto, } \\
\text { University of California, Davis }\end{array}$ & {$[16]$} \\
\hline & Black & $\begin{array}{l}\text { J. K. Yamamoto, } \\
\text { University of California, Davis }\end{array}$ & {$[2,14]$} \\
\hline FECV & $79-1683$ & $\begin{array}{l}\text { A. J. McKeirnan, } \\
\text { Washington State University, Pullman }\end{array}$ & {$[12,20]$} \\
\hline \multirow[t]{2}{*}{ TGEV } & TO-163 & $\begin{array}{l}\text { National Institute of Animal } \\
\text { Health of Japan }\end{array}$ & [4] \\
\hline & SH & $\begin{array}{l}\text { National Institute of Animal } \\
\text { Health of Japan }\end{array}$ & {$[6]$} \\
\hline $\mathrm{CCV}$ & $1-71$ & $\begin{array}{l}\text { E. Takahashi, } \\
\text { University of Tokyo }\end{array}$ & {$[1]$} \\
\hline
\end{tabular}

\section{Preparation of virus antigen}

The antigen was prepared with the FIPV 79-1146 strain grown in fcwf -4 cell cultures. Infectious culture fluid concentrated about tenfold by ammonium sulfate precipitation was layered onto a discontinuous sucrose density gradient $(20$ and $60 \%$ ) in a RPS 28 rotor (Hitachi Koki Co., Ltd, Japan) and centrifuged at 27,000 r.p.m. for 2 h. The virus bands formed at the interface of $20 \%$ and $60 \%$ sucrose layers were collected, diluted in NTE buffer $(0.1 \mathrm{M} \mathrm{NaCl}, 0.01 \mathrm{M}$ Tris-HCl, $\mathrm{pH} 7.4,0.001 \mathrm{M}$ EDTA $)$ and centrifuged at $80,000 \times \mathbf{g}$ for $1 \mathrm{~h}$. The virus-containing pellet was suspended in a 1/500 volume of NTE buffer.

\section{Production of antibody-secreting hybridomas}

For preparation of neutralizing MAbs against FIPV 79-1146 strain, BALB/c mice, about 5 weeks of age, were inoculated intraperitoneally with a mixture of $50 \mu \mathrm{g}$ of the viral antigen prepared as above and $10^{9}$ cells of pertussis adjuvant. Four or 6 weeks later the mice received an intravenous booster dose of $50 \mu \mathrm{g}$ of viral antigen, and spleen cells were obtained for fusion 3 days later. The fusion was carried out by essentially the same method described by Köhler and Milstein [11]. Polyethyleneglycol-4,000 (Merck, Federal Republic of Ger- 
many) was used as a fusing agent and the ratio of mouse spleen cells and mouse myeloma cells (P-3/X-63-Ag8-6,5,3) was 10:1. The selective medium contained hypoxanthine $\left(10^{-4} \mathrm{M}\right)$, aminopterin $\left(4 \times 10^{-7} \mathrm{M}\right)$ and thymidine $\left(1.6 \times 10^{-5} \mathrm{M}\right)$. The fused cells, at a concentration of $3.5 \times 10^{6}$ spleen cells per $\mathrm{ml}$, were dispended in $100 \mu \mathrm{l}$ volumes into wells of 96-well, flat-bottomed microplates (Corning Glass Works, Corning, NY) and incubated at $37^{\circ} \mathrm{C}$ in a humid atmosphere containing $5 \% \mathrm{CO}_{2}$. After incubation for 2 weeks, the wells were examined and those which contained hybridoma cultures were tested for feline coronavirus specific antibody by a neutralization (NT) test (see below). The colonies in antibody positive wells were passaged in 24-well multiplates (Corning Glass Works, Corning, $\mathrm{NY})$ and incubated in medium containing hypoxanthine $\left(10^{-4} \mathrm{M}\right)$ and thymidine $\left(1.6 \times 10^{-5} \mathrm{M}\right)$. The cells were then cloned by the soft agar method.

The neutralizing MAbs against TGEV TO-163 strain used were previously reported by Hohdatsu et al. [7].

\section{Determination of antibody class and subclass}

The supernatant fluid of antibody-secreting hybridoma cultures were concentrated tenfold by $50 \%$ saturation of ammonium sulfate and used for determination of antibody class and subclass by double diffusion in $1 \%$ agar gel containing $0.1 \% \mathrm{NaN}_{3}$. Rabbit antisera against mouse immunoglobulins, $\operatorname{IgG} 1, \operatorname{IgG} 2 \mathrm{a}, \operatorname{IgG} 2 \mathrm{~b}, \operatorname{IgG} 3, \operatorname{IgM}$ and $\operatorname{IgA}$, and $\kappa$ and $\lambda$ chains (Miles Laboratories, Naperville, U.S.A.) were placed in center wells and test samples were added to peripheral wells. The plates were incubated overnight at room temperature in a humidified chamber.

\section{Sodium dodecyl sulfate-polyacrylamide gel electrophoresis (SDS-PAGE)}

SDS-PAGE was performed in slab gels under a nonreducing condition. The separation gel contained $10 \%$ polyacrylamide and the stacking gel contained $3 \%$ polyacrylamide. The sample buffer contained final concentration of $2 \%(\mathrm{w} / \mathrm{v})$ SDS, $10 \%(\mathrm{v} / \mathrm{v})$ glycerol, $0.1 \%$ $(\mathrm{w} / \mathrm{v})$ bromphenol blue and $100 \mathrm{mM}$ Tris- $\mathrm{HCl}(\mathrm{pH} 6.8)$. The electrode buffer ( $\mathrm{pH} 8.8)$ contained $6.1 \mathrm{~g} / 1$ Tris, $28.8 \mathrm{~g} / 1$ glycine and $0.1 \%$ SDS. Samples were mixed with sample buffer and kept at room temperature for $12 \mathrm{~h}$ without boiling. Electrophoresis was performed at room temperature for $6 \mathrm{~h}$ at a constant current of $20 \mathrm{~mA}$.

\section{Western immunoblotting}

Viral antigen separated in polyacrylamide gel by SDS-PAGE were transferred to nitrocellulose sheets of $0.45 \mu \mathrm{m}$ pore size. The transfer was carried out electrophoretically by the method adapted from Towbin et al. [24] in a Transfer-Blot cell apparatus (Bio-Rad Laboratories, Richmond, $\mathrm{CA}$ ) at $120 \mathrm{~mA}$ and $10 \mathrm{~V}$ for $14 \mathrm{~h}$ using transfer buffer consisting of $3 \mathrm{~g} / 1$ Tris ( $\mathrm{pH} 8.3$ ), 20\% methanol and $43.2 \mathrm{~g} / 1$ glycine. The nitrocellulose sheets were then cut into strips and incubated at $37^{\circ} \mathrm{C}$ for $2 \mathrm{~h}$ in PBS containing $10 \%$ fetal calf serum. The supernatant fluid of antibody-secreting hybridoma cultures were added in $1 \mathrm{ml}$ volumes to individual strips and incubated at $37^{\circ} \mathrm{C}$ for $2 \mathrm{~h}$. The strips were then washed 3 times with PBS containing $0.05 \%$ Tween-20, and incubated at $37^{\circ} \mathrm{C}$ for $2 \mathrm{~h}$ with horseradish peroxidase-conjugated rabbit antibody against mouse IgG, IgA, and IgM (Miles Lab., U.S.A.) diluted 1:300 with PBS containing $10 \%$ fetal calf serum. The strips were then washed and treated with substrate solution containing $0.05 \mathrm{~g}$ diaminobenzidine, $50 \mu \mathrm{l}$ of $30 \% \mathrm{H}_{2} \mathrm{O}_{2}$ in $100 \mathrm{ml}$ of $0.05 \mathrm{M}$ Tris- $\mathrm{HCl}, \mathrm{pH} 7.2$. When distinct bands appeared about $10 \mathrm{~min}$ later, the reaction was stopped by pouring off the substrate solution and rinsing with distilled water. 
This was carried out by a modified enzyme-linked immunosorbent assay (ELISA) [10]. Serial tenfold dilutions in $100 \mu \mathrm{l}$ volumes of each competing MAb from ascitic fluid were added to wells of a flat-bottomed Microelisa plate coated with virus antigen (see above), and incubated at $37^{\circ} \mathrm{C}$ for $60 \mathrm{~min}$. After 3 washings with washing solution $(0.85 \% \mathrm{NaCl}$ solution containing $0.02 \%$ Tween-20), $100 \mu \mathrm{l}$ of biotin-labeled MAb diluted so as to show an optical density (OD) of 1.0 was added, and incubated at $37^{\circ} \mathrm{C}$ for $60 \mathrm{~min}$. After 3 washings with washing solution, peroxidase conjugated avidin (Cappel, Cooper Biomedical, Inc. Malvern, PA) were diluted to the optimal concentration with PBS containing $10 \%$ fetal calf serum and $0.05 \%$ Tween- 20 and $100 \mu \mathrm{l}$ of the dilution was added to each well of the plates. After incubation at $37^{\circ} \mathrm{C}$ for $30 \mathrm{~min}$, each well received $100 \mu \mathrm{l}$ of substrate solution and incubated at $25^{\circ} \mathrm{C}$ for $20 \mathrm{~min}$ in a dark room. After completion of the incubation, the reaction was stopped with $3 \mathrm{~N} \mathrm{H}_{2} \mathrm{SO}_{4}$ solution and the OD at $492 \mathrm{~nm}$ was determined. The amount of competitive binding was estimated from the OD in the presence or absence of unlabeled competing antibodies. The percentage of competition was determined by the formula, $100(A-n) /(A-B)$, where $A$ is the OD in the absence of competing antibody, $B$ is the OD in the presence of homologous antibody $\left(10^{4}\right.$ ELISA units), and $n$ is the OD in the presence of a competitor.

\section{Neutralization (NT) test}

Serial twofold dilutions of the MAb were mixed with an equal volume of a virus suspension diluted so as to contain approximately $200 \mathrm{TCID}_{50} / 0.1 \mathrm{ml}$. The mixtures were incubated at $37^{\circ} \mathrm{C}$ for $60 \mathrm{~min}$. Each mixture was then inoculated into cell cultures in flat-bottomed microplates (Corning Glass Works, Corning, NY), and incubated in an atmosphere of $5 \%$ $\mathrm{CO}_{2}$ in air at $37^{\circ} \mathrm{C}$ for 6 days. Two wells were employed for each antibody dilution. The anitbody titer was expressed as the reciprocal of the highest dilution of MAb that completely inhibited cytopathic effect in the test.

\section{Results}

\section{Isolation and characterization of monoclonal antibodies}

Using the spleen cells of mice immunized with FIPV strain 79-1146, cell fusion was conducted 6 times. As a result, 7 MAbs (5-6-2, 5-7-2, 6-1-1, 6-4-2, 7-1-1, 7-3-1, and 7-4-1) with neutralizing activity against FIPV strain 79-1146 were obtained. The immunoglobulin isotype and polypeptide specificity of these MAbs are shown in Table 2. Polypeptide specificity was determined by Western immunoblotting. All Mabs were found to recognize the S protein of the viruses. Figure 1 shows an example of the reaction.

\section{Results of competitive binding assay}

To determine the differences in the epitope specificity of the 7 neutralizing MAbs, competitive binding assay was performed, and the results are summarized in Table 3. Binding of the biotin-labeled MAbs 5-6-2, 5-7-2, 7-1-1, and 7-3-1 to virus antigen was completely blocked by all of these unlabeled MAbs. The biotin-labeled MAb 7-4-1 was completely blocked only by the homologous MAb. Biotin-labeled MAbs 6-4-2 and 6-1-1 were completely blocked by all unlabeled MAbs. Unlabeled MAbs 6-4-2 and 6-1-1 blocked biotin-labeled MAbs 
Table 2. Immunoglobulin isotype and polypeptide specificity of monoclonal antibodies

\begin{tabular}{llll}
\hline MAb no. & \multicolumn{2}{l}{ Isotype } & \multirow{2}{*}{ Polypeptide specificity } \\
\cline { 2 - 3 } & heavy chain & light chain & \\
\hline $5-6-2$ & IgG 1 & $\kappa$ & $\mathrm{S}$ \\
$5-7-2$ & IgG 2a & $\kappa$ & $\mathrm{S}$ \\
$6-1-1$ & IgG 1 & $\kappa$ & $\mathrm{S}$ \\
$6-4-2$ & IgG 2a & $\kappa$ & $\mathrm{S}$ \\
$7-1-1$ & IgG 2a & $\kappa$ & $\mathrm{S}$ \\
$7-3-1$ & IgG 1 & $\kappa$ & $\mathrm{S}$ \\
$7-4-1$ & IgG 2 b & $\kappa$ & $\mathrm{S}$ \\
\hline
\end{tabular}

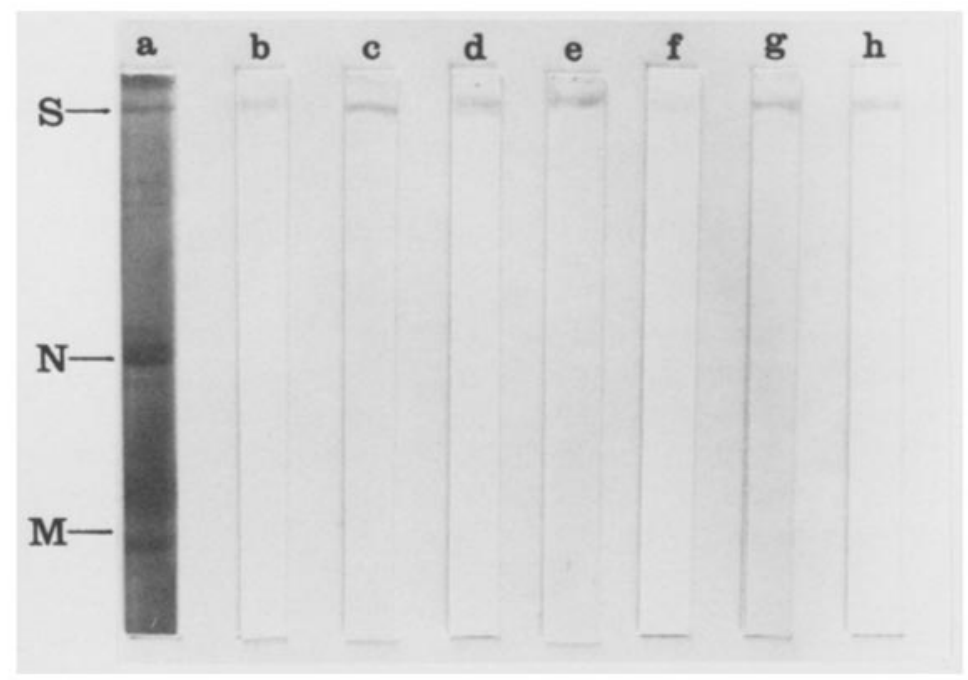

Fig. 1. Polypeptide specificity of neutralizing MAbs against FIPV 79-1146 strain in Western immunoblotting. $a$ Anti-FIPV mouse serum, $b$ 5-6-2, $c$ 5-7-2, $d 7-1-1, e$ 7-3-1, f 7-4-1, $g$ 6$1-1, h 6-4-2$

Table 3. Results of competitive binding assay

\begin{tabular}{|c|c|c|c|c|c|c|c|c|}
\hline \multirow{2}{*}{$\begin{array}{l}\text { Biotin } \\
\text { labelled } \\
\text { MAb }\end{array}$} & \multicolumn{7}{|c|}{ Unlabelled MAb } & \multirow{2}{*}{$\begin{array}{l}\text { Epitope } \\
\text { specificity }\end{array}$} \\
\hline & $5-6-2$ & $5-7-2$ & $7-1-1$ & $7-3-1$ & $7-4-1$ & $6-4-2$ & $6-1-1$ & \\
\hline $5-6-2$ & + & + & + & + & - & 49.8 & 34.1 & I \\
\hline $5-7-2$ & + & + & + & + & - & 65.1 & 57.6 & I \\
\hline $7-1-1$ & + & + & + & + & - & 67.3 & 67.9 & I \\
\hline $7-3-1$ & + & + & + & + & - & 50.2 & 38.0 & I \\
\hline $7-4-1$ & - & - & - & - & + & 76.4 & 75.4 & II \\
\hline $6-4-2$ & + & + & + & + & + & + & + & III \\
\hline $6-1-1$ & + & + & + & + & + & + & + & III \\
\hline
\end{tabular}

+ Represents $\geqslant 80 \%$ inhibition of binding

- Represents $\leqslant 20 \%$ inhibition of binding 

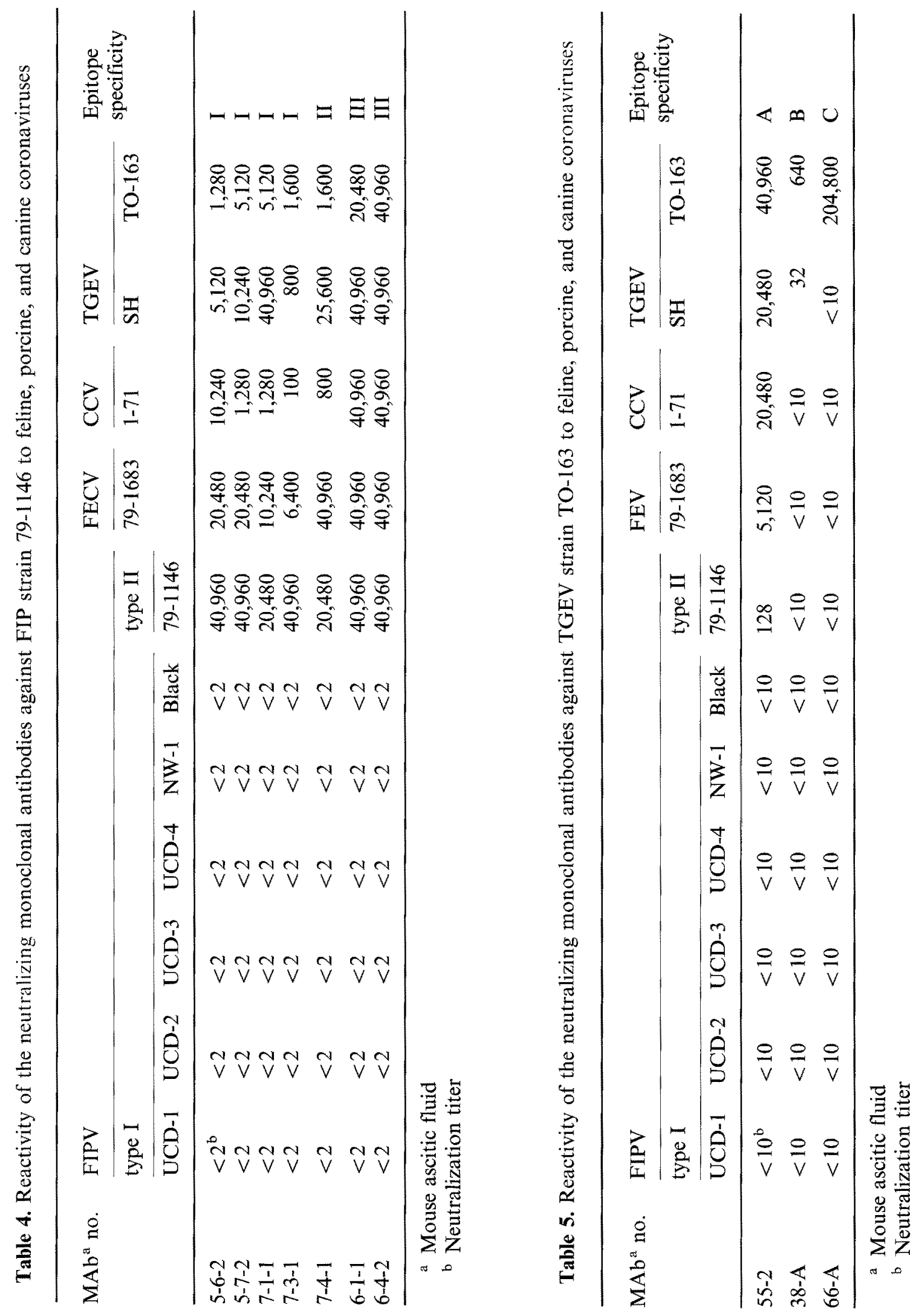
$5-6-2,5-7-2,7-1-1,7-3-1$, and $7-4-1$ by $34.1 \sim 76.4 \%$. On the basis of these results, epitopes recognized by these MAbs were named I, II, and III.

Reactivity of the neutralizing MAbs against FIPV strain 79-1146 with feline, porcine, and canine coronaviruses

Reactivity of the MAbs which recognize the 3 neutralizing epitopes in FIPV strain 79-1146, with feline, porcine, and canine coronaviruses was investigated with the neutralization (NT) test. As shown in Table 4, these MAbs did not neutralize the 6 FIPV type I strains, but neutralized FECV strain 79-1683, as well as the porcine and canine coronaviruses. In particular, MAbs which recognize epitope III (6-1-1 and 6-4-2) also showed a high neutralizing activity against these viruses, as against FIPV strain 79-1146.

Reactivity of the neutralizing $M A b s$ against TGEV strain TO-163 with feline, porcine, and canine coronaviruses

The reactivity of the 3 neutralizing MAbs (55-2, 38-1, and 66-A) [7] prepared by using TGEV strain TO-163 as immunogen, with feline, canine, and porcine coronaviruses was examined with the NT test. All these 3 MAbs recognize different epitopes of the $\mathrm{S}$ protein of TGEV. Among these MAbs, MAb 55-2 possesses a strong neutralizing activity 1:12,800 1:40,960) against 7 TGEV strains (TO-163, h-5, Kanagawa, Purdue, Ukiha, SH, Miller strains), and similarly, MAb 38-A has a weak neutralizing activity $(1: 8 \sim 1: 640)$ against the 7 TGEV strains. MAb 66-A possesses a neutralizing activity only against the TO$163, \mathrm{~h}-5$ and Kanagawa strains of TGEV.

The results are shown in Table 5. While MAb 55-2 neutralized the FIPV type II strain 79-1146, FECV type II strain 79-1683, and CCV strain 1-71, it did not neutralize FIPV type I viruses. MAbs 38-A and 66-A did not neutralize any coronaviruses other than TGEV.

\section{Discussion}

In this study, we prepared 7 MAbs with neutralizing activity against FIPV strain 79-1146, and used them to investigate the serological relationships between feline, porcine, and canine coronaviruses.

It is generally accepted that epitopes associated with neutralization are present on the $\mathrm{S}$ protein of viruses. Fiscus and Teramoto have reported this phenomenon in feline coronaviruses [3]. All 7 MAbs with neutralizing activity were observed to recognize $S$ protein. This finding confirms the presence of a neutralizing epitope on the $S$ protein. However, there have been no reports on the characteristics of this epitope. The results of the competitive binding assay using the 7 MAbs revealed the existence of at least 3 different neutralizing epitopes (I, II, and III) in FIPV strain 79-1146 (Table 3). We believe that the topographical relationship between epitopes I, II, and III is as follows. Since 


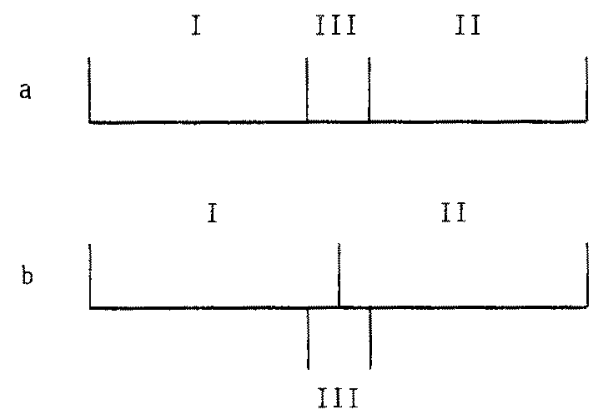

Fig. 2. Model for the location of the epitopes recognized by our panel of neutralizing monoclonal antibodies against FIPV 79-1146 strain

MAbs which recognize epitopes I and II did not inhibit the binding of each other's biotin-labeled MAb to the virus antigen, they were considered to exist independently. In contrast, 2 MAbs which recognize epitope III were inhibited by all unlabeled MAb. Moreover, the unlabeled MAb of epitope III inhibited the labeled MAbs of epitopes I and II by $34.1 \sim 76.4 \%$. Consequently, it was postulated that epitope III exists at an intermediate site between epitopes I and II, very close to both epitopes (Fig. 2 a) resulting in blocking by steric hindrance, or that epitope III overlaps part of epitopes I and II (Fig. 2 b).

Differences in the epitopes recognized by the 7 MAbs were determined. The NT activity of these 7 MAbs against several feline, porcine, and canine coronaviruses was examined. These MAbs did not neutralize the 6 FIPV type I viruses, but neutralized FECV strain 79-1683, TGEV strains TO-163 and SH, and CCV strain 1-71, which do not cause feline infectious peritonitis (Table 4). Moreover, a MAb against TGEV strain TO-163, which neutralized the 7 TGEV strains, neutralized FIPV strain 79-1146, FECV strain 79-1683, and CCV strain 1-71 (Table 5). These results support the classification by Pedersen et al. [17]. When the 5 virus groups (FIPV type I, FIPV type II, FECV type II, TGEV, and CCV) are serologically compared, FIPV type II, FECV type II, TGEV, and $\mathrm{CCV}$ are found to form a group. FIPV type I virus seems to be a virus of a distinct serotype. In other words, FIPV inducing feline infectious peritonitis seem to consist of viruses of at least 2 serotypes. Pedersen et al. [17] have indicated that many cases of feline infectious peritonitis in cats are induced by type I virus infection. We also found that, out of 24 cats with feline infectious peritonitis-like symptoms and antibody-positive by indirect fluorescent antibody assay, only 6 were positive for neutralizing antibody against FIPV strain 791146 (FIPV type II) (unpubl. data). It is probable that FIPV type I is more prevalent in a natural environment. In the future, examination of the effects of different virus types on the anitbody-mediated enhancement of FIPV infection $[15,26]$, as seen in dengue virus infection $[5,13]$, would be valuable. At present, we are investigating the effects of the neutralizing MAb prepared in this study against in vivo FIPV infection. Differences between TGEV strain Purdue and FIPV type II strain 79-1146 at the gene level of S protein have been reported [9]. Analysis of FIPV type I at the gene level is also desired. 


\section{Acknowledgements}

This work has been funded by the Kitasato Research Foundation under Grant No. 6.

\section{References}

1. Binn LN, Lazer EC, Keenan KP, Huxsoll DL, Marchwicki RH, Strano AJ (1975) Recovery and characterization of a coronavirus from military dogs with diarrhoea. In: Proceedings 78th Annual Meeting US Animal Health Association, pp 359-366

2. Black JW (1982) Recovery and in-vitro cultivation of a coronavirus from laboratoryinduced cases of feline infectious peritonitis (FIP). Vet Med [Small Anim Clin] 75: $811-814$

3. Fiscus SA, Teramoto YA (1987) Antigenic comparison feline coronavirus isolates: evidence for markedly different peplomer glycoproteins. J Virol 61: 2607-2613

4. Furuuchi S, Shimizu Y, Kumagai T (1975) Comparison between virulent and attenuated strains of transmissible gastroenteritis virus. Natl Inst Anim Health Q 15: 159-164

5. Halstead SB, Venkateshan CN, Gentry MK, Larsen LK (1984) Heterogeneity of infection enhancement of dengue 2 strains by monoclonal antibodies. J Immunol 132: $1529-1532$

6. Harada K, Kumagai T, Sasahara J (1967) Studies on transmissible gastroenteritis in pigs. III. Isolation of cytopathogenic virus and its use for serological investigation. Natl Inst Anim Health Q 7: 127-137

7. Hohdatsu T, Eiguchi Y, Tsuchimoto M, Ide S, Yamagishi H, Matumoto M (1987) Antigenic variation of porcine transmissible gastroenteritis virus detected by monoclonal antibodies. Vet Microbiol 14: 115-124

8. Horzinek MC, Lutz H, Pedersen NC (1982) Antigenic relationships among homologous structural polypeptides of porcine, feline and canine coronaviruses. Infect Immun 37: 1148-1155

9. Jacobs L, Groot RD, Van der Zeijst BAM, Horzinek MC, Spaan WJM (1987) The nucleotide sequence of the peplomer gene of porcine transmissible gastroenteritis virus (TGEV): comparison with the sequence of the peplomer protein of feline infectious peritonitis virus (FIPV). Virus Res 8: 363-371

10. Kimura-Kuroda J, Yasui K (1983) Topographical analysis of antigenic determinants on envelope glycoprotein $V_{3}$ (E) of Japanese encephalitis virus, using monoclonal antibodies. J Virol 45: 124-132

11. Köhler G, Milstein C (1975) Continuous cultures of fused cells secreting antibody of predefined specificity. Nature 256: 495-497

12. McKeirnan AJ, Evermann JF, Hargis A, Miller LM, Ott RL (1981) Isolation of feline coronaviruses from two cats with diverse disease manifestations. Feline Pract 11: 16-20

13. Morens DM, Venkateshan CN, Haelstead SB (1987) Dengue 4 virus monoclonal antibodies identify epitopes that mediate immune infection enhancement of dengue 2 viruses. J Gen Virol 68: 91-98

14. Pedersen NC, Black WB (1983) Attempted immunization of cats against feline infectious peritonitis, using avirulent live virus or sublethal amounts of virulent virus. Am J Vet Res 44: 229-234

15. Pedersen NC, Boyle JF (1980) Immunologic phenomena in the effusive form of feline infectious peritonitis. Am J Vet Res 41: 868-876

16. Pedersen NC, Floyd K (1985) Experimental studies with three new strains of feline infections peritonitis virus: FIPV-UCD 2, FIPV-UCD 3 and FIPV-UCD 4. Comp Cont Educ Prac Vet 7: 1001-1011

17. Pedersen NC, Black JW, Boyle JF, Evermann JF, McKeirnan AJ, Ott RL (1984) Pathogenic differences between various feline coronavirus isolates. Adv Exp Med Biol 173: $365-380$ 
18. Pedersen NC, Boyle JF, Floyd K (1981) Infection studies in kittens utilizing feline infections peritonitis virus propagated in cell culture. Am J Vet Res 42: 363-367

19. Pedersen NC, Boyle JF, Floyd K, Fudge A, Barker J (1981) An enteric coronavirus infection of cats and its relationship to feline infectious peritonitis. Am $J$ Vet Res 42: 368-377

20. Pedersen NC, Evermann JF, McKeirnan AJ, Ott RL (1984) Pathogenicity studies of feline coronavirus isolates 79-1146 and 79-1683. Am J Vet Res 45: 2580-2585

21. Pedersen NC (1976) Morphologic and physical characteristics of feline infectious peritonitis virus and its growth in autochthonous peritoneal cell cultures. Am J Vet Res 37: $567-572$

22. Pedersen NC, Ward J, Mengeling WL (1978) Antigenic relationship of the feline infectious peritonitis virus to coronaviruses of other species. Arch Virol 58: 45-53

23. Siddell SG, Anderson R, Cavanagh D, Fujiwara K, Klenk HD, Macnaughton MR, Pensaert M, Stohlman SA, Sturman L, Van der Zeijst BAM (1983) Coronaviridae. Intervirology 20: 181-189

24. Towbin H, Staehelin T, Gordon J (1979) Electrophoretic transfer of proteins from polyacrylamide gels to nitrocellulose sheets: procedure and some applications. Proc Natl Acad Sci USA 76: 4350-4354

25. Tyrrell DAJ, Alexander DJ, Almeida JD, Cunningham CH, Easterday BC, Garwes DJ, Hierholzer JC, Kapikian A, Macnaughton MR, McIntosh K (1978) Coronaviridae: second report. Intervirology 10: 321-328

26. Weiss RC, Scott FW (1981) Antibody-mediated enhancement of disease in feline infectious peritonitis: comparison with dengue hemorrhagic fever. Comp Immun Microbiol Infect Dis 4: 175-189

Authors' address: T. Hohdatsu, Department of Veterinary Microbiology, School of Veterinary Medicine and Animal Sciences, Kitasato University, Towada, Aomori 034, Japan.

Received June 27, 1990 